\title{
Foreword
}

PROFESSOR Dennis Ogawa has given us a dramatic story of how Japanese Americans in Hawaii have maintained continuity with their ancestral roots while contributing to a more peaceful, harmonious America. It is a story we need to hear and learn from as we read daily of how ethnic tribalisms in other parts of the world are tearing nations apart. The outcome is also quite different from that predicted for this country by Michel-Guillaume Jean de Crèvecoeur in his Letters From an American Farmer on the eve of the American revolution. Observing ethnic diversity around him-the English, Scots, Irish, French, Dutch, Germans and Swedes-Crèvecoeur predicted that out of this "promiscuous breed" would come "the American" who leaves behind "all his ancient prejudices and manners," acting only upon new principles. That the descendants of immigrants have acted on new principles is true, but ethnic cultures have not disappeared under the impact of liberal, individualistic principles as Crèvecoeur thought they would.

To the contrary. In the post World War II decades, the very time when liberalism made its greatest strides, we have seen a resurgence of ethnic consciousness. Instead of destroying ethnic identities, the emerging liberal civic culture of the twentieth century has made it possible for language and religious schools and other expressions of ethnic culture to flourish. The strength of liberalism is that it permits individuals to express their individuality through group identities if they choose; the weakness of liberalism is that it fails to offer the 


\section{xiv FOREWORD}

kind of deep, emotional enrichment which ties to organic ethnic history provide. Ethnic consciousness prospers on both accounts. Yet, liberalism has not suffered seriously thus far. Agreement on liberal constitutional principles has become the basis not just of American consensus but of a civic American identity. Because American identity is no longer defined by color, religion, language, or any other tribalistic symbol, the Amish, Hutterites, Hasidic Jews, Seventh Day Adventists, Jehovah's Witnesses, Hungarians, Cubans, or others are free to be as ethnic as they wish without being any less American as long as they abide by the noncoercive ideals and rules of the civic culture.

We owe much to Japanese Americans for our emancipation from a racist, linguistic, or religious definition of Americanism. Partly because of them, immigration policy is no longer racist; to a large extent because of them we no longer believe with Theodore Roosevelt or Woodrow Wilson that Americans must speak only English in public discourse; and almost entirely because of them we realize that the children of immigrant Americans can assert primary loyalty to the United States even when it is fighting a war against a nation to which their parents were deeply loyal.

While the Japanese Americans in Hawaii have contributed disproportionately to the civic meaning of American identity, they have also given something to its cultural definition. In this book we learn just how Japanese Americans have participated-and continue to participate-in a dynamic process of cultural diffusion within an ideal framework of protection for individual rights and reward for individual achievement. Rather than melting, ethnic groups have been molting as animals do when they shed feathers or skin in the process of renewal. But even the molting metaphor is misleading as we attempt to describe ethnic group acculturation in the United States. No single word or phrase can possibly capture the dynamic, complex process of cultural diffusion in which Japanese have changed over time but have also changed the rest of us. Ogawa gives us flavor and insight into that process in his description of Urabon, the annual Buddhist festival corresponding with the July full moon, held in the small rural community of Haleiwa. He takes us into the transmogrified Urabon from the perspectives of issei, nisei, sansei, yonsei, haoles and others. Urabon is no longer a Buddhist Japanese festival only, but a many-sided religious, secular, American, Hawaiian island, Buddhist, and Japanese occasion for expressing ethnic distinctiveness while sharing and modifying it at the same time. 
As Ogawa takes us on a tour of the festival from many perspectives, he makes us realize that while few Japanese or non-Japanese understand the religious significance of the Urabon-the joining of the dead in a belief of karma, wisdom, and compassion-it has acquired new meanings synthesizing the experiences of the Japanese in Hawaii.

The continuity with the past is explicit for the issei: "To sing the old chants, to dance the ancient steps, seems to link the soul with ... ancestry as if the genetic code contained choreography and musical scores." But even for the issei, Buddhism could not remain as it had been in Japan. Just as Buddhism there became uniquely Japanized through the influence of Shintoism (and Confucianism and Taoism), Buddhism in Hawaii became Americanized by the influence of Christianity, the civic culture and other aspects of the American milieu.

While Professor Ogawa is particularly vivid in his descriptions and selections as to how the Japanese adapted to and were changed by the American environment, he makes it clear that such vital Japanese values as enryo (self restraint), haji (shame), on (obligation to family and community), kosai (the kin and friendship networks to which one is obligated), and giri (reciprocity to obligation) have not disappeared. They have been renewed and changed and given new modes of expression, and not for Japanese only. All non-Japanese who live and work in Hawaii are touched by such values, especially those who marry with sansei or yonsei.

One Japanese value, seiko (success), fits the American environment extremely well. Without some basis for achievement motivation, the American principle of economic reward for individual achievement becomes a punishing illusion. Seiko, of course, was linked to family pride and obligation in Japan and even in Hawaii. One studied and worked hard to succeed for the family, not for oneself. But the results in terms of economic mobility were the same. Impelled by seiko, many issei and nisei found mobility ladders even in the repressive, restricted plantation system and especially beyond it in the towns of Honolulu and Hilo. By the time of the sansei and yonsei, pure seiko had been combined with the American drive for individual success.

One of the most fascinating things about the Japanese experience in Hawaii is that economic success has not destroyed on and giri among family members. Contrasted to Jewish Americans, for example, whose high mobility has been accompanied by great difficulty in 
maintaining extended kin networks, the third- and fourth-generation Japanese in Hawaii show considerable reliance on families through various forms of giri. The Japanese patriarchal ie (household) was weakened, of course, but the Japanese kosai, the large network of close family, relatives, and friends to whom one felt obligated and who, in turn, reciprocated, was maintained and adapted to island circumstances. Hawaii's island insularity kept the kosai active since economic mobility did not mean physical movement from one end of a big continent, or even from one city to another.

Of course, as Ogawa shows, new problems have replaced old ones and new roles and functions must be negotiated between the sexes and the generations under the impact of the American emphasis on independence and equality. In these matters, Ogawa shows no sympathy for the patriarchal hierarchy of old, although he reveals great sensitivity and concern-perhaps stemming from his Japanese roots -over the neglect and hurting of the aged so common in the United States. In addition, he displays an empathy for Japanese American women who suffer new conflicts because of the new expectations and demands which the American environment encourages. The familymindedness of Professor Ogawa-as he looks at the strains and stresses of the nisei and sansei families-helps him to lift ethnic history into a larger humanistic context.

That humanism is reflected in the importance which Ogawa gives to such haole leaders as Miles Cary, Benjamin Wist, Frank Midkiff, John Burns, David Thompson, and Andrew Lind, and especially to the important places which he has assigned to the Reverends Yemyo Imamura and Takie Okumura in the unfolding of the Japanese story in Hawaii. Imamura, the bishop of the Buddhist Honpa Hongwanji until 1932, often criticized for redirecting Buddhist institutions to accommodate to Christianity, is no Uncle Tom to Ogawa, but a loving, compassionate man trying to help issei and nisei live comfortably in a new and disorienting place. Okumura, who was a vigorous Christianizer and Americanizer is not portrayed here as "selling out." Rather it was Okumura's vision of American pluralism which eventually materialized in Hawaii. Like Ogawa, he foresaw a way of life for Americans of Japanese ancestry which would synthesize elements of the old and new without leading to political and economic servility.

An expression of synthesizing with which Ogawa is in sympathy is the emergence of pidgin English, that remarkably emotive mixture of many languages which came from the multiethnic experience of 
Hawaii's plantations. Ogawa correctly calls on the writings of haole John Reinecke, the scholar whose work on the two disparate fields of language and labor in Hawaii remains unrivaled, to tell about pidgin.

If there is anything missing in this fascinating saga of the Japanese-American experience in Hawaii it is a touch of pessimism. The optimism in this book prevails even in Glen Grant's concluding essay on race relations in the Hawaiian school. Grant shows convincingly that it is possible for school children of different ethnic backgrounds to negotiate points of commonality even when they openly express hostility to each other in school. Perhaps in another book Ogawa will face head-on the serious threats to his vision of pluralism in Hawaii. Now that they are relatively successful and powerful, Japanese Americans have become the targets of antagonisms expressed by the relatively poor and powerless Filipinos, Samoans and part Hawaiians. But Ogawa does not permit darker themes of resentment against Japanese success to mar his positive view of the Japanese experience in Hawaii or his hopes for ethnic harmony in the islands.

The author is an idealist who correctly finds confirmation of his humanism in his experience of Japanese Americans in Hawaii. At a time when retribalization the world over often results in torture and murder, Ogawa shows us how men and women can have some of the best of their tribalism and humanism, too. Perhaps they can, at least in the United States (with the possible exception of those natives who were conquered by the Anglo-Europeans), since First Amendment freedoms do permit one to be as ethnic as one likes while at the same time they impose limits to the destructive expression of ethnic values and interests. That is the hope implicit in this remarkable story.

By insisting that ethnic differences can enrich rather than destroy humanity, Ogawa hitches his scholarly talents and poetic insights to the party of hope. As impressed as he is by his inheritance from the past ("Okage sama de"-_"I am what I am because of you") and by his obligation to the future ("kodomo no tame ni"--"for the sake of the children"), his sense of hope is contagious. For his scholarship, insight, and optimism we should all say mahalo nui loa.

LAWRENCE H. FUCHS 
